\title{
Development Center For Digital Government Cooperation Patterns Of Small Medium Enterprises-Private To The Acceleration Of Economic Increase In Tourist Areas
}

\author{
Joko Suyono ${ }^{1}$, I Nyoman Sudapet ${ }^{2}$ \\ ${ }^{12}$ Narotama University \\ ikhsan.setiawan@narotama.ac.id
}

\begin{abstract}
Received : $\quad$ May 10, $2017 \quad$ Accepted : $\quad$ August 13, 2017
ABSTRACT

The infrastructure budget reached Rp 290 Billion in APBN-P (Budget spending Revenue State changes) in 2015 be consist of opportunities for investors and Government Areas, this will be trigger an increase in the central area of UKM. 2014 year Indonesia stock exchange noted the value of market capitalization (market cap) to the property sector, real estate, and construction of the building reached Rp 360 Billion (idx, 2014). Bank Indonesia survey showed a significant increase in the selling price of units of strata title in Jabodetabek and Bandung, Banten segment of Office, retail, industrial, land and condominiums as well as commercial property rental rates increased and the price of the hotel star 3,4 and 5 (BI, 2014). Autonomous region through Act No. 22/1999 and no. 34/2004 demanding pemerintah progoverment province, city creative increase revenue areas. BUDGETS (Revenue Budget spending Area) year 2013 deficit financial area reached Rp 54.217 trillion (Kemendagri, 2013). The development of the digital hub of Micro, small, and medium enterprises (UMKM) area can be a collaboration between Central Government, local governments, State-Owned Enterprises, Local, and private sector.
\end{abstract}

(C) 2017 Published By IJTI. This is an Open Acces article under the CC BY SA License https://creativecommons.org/licenses/by-sa/4.0/

Keyword : Digital Sentry SMEC Area, Market Capitalization, Autonomous Region

\section{INTRODUCTION}

Indonesia ranked second in global investment based on the Economist Corporate Network Asia Business Outlook Survey 2014 (Economist, 2015), as well as fourth place according to the UNCTAD World Investment Prospect 2013-2015 (UNCTAD, 2015). Boston Consulting Group declared an increase in the population of the middle class in Indonesia reached 74 million (2013) and 141 million (2020) one of which encourage consumer spending in the form of ownership/investment property (Boston Consulting Group, 2013). Capital investment Coordination Board stating the investment realization PMDN (investing in the country) and PMA (Private capital investment), the construction sector, housing, industrial areas, offices, hotels and restaurants has increased significantly since the year 2010, the year 2014 which reached Rp. 25.66 billion (capital investment Coordination Board, 2014). The growing prospect of a business centre (central business district) encourage local governments to cooperate with private parties to obtain an increase in the income of the region. Autonomous region through Act No. 22/1999 and no. 34/2004 demanding Groverment Province, City creative increase revenue areas, it looks at the Revenue Budget Spending Area year 2013 with a financial deficit of the region reached Rp 54.217 trillion (Ministry of the Interior, 2013). Regional income potential should be able to cover the deficit when viewing the report balance sheet local government of indonesia in the year 2010 there are local government land assets valued at Rp 558.456 Billion and asset building government/buildings worth Rp 228.343 trillion (Ministry of the Interior, 2010). Business development regional property can be a collaboration between Central Government, local governments, State-Owned Enterprises, Local, and private sector. Public-Private Partnership (public private 
partnership) became one of the area's economy and improvement solutions have been proven in some of the neighbouring countries, among others, in Malaysia and Singapore. The infrastructure budget reached Rp 290 Billion in STATE BUDGET-P (Budget Spending Revenue State changes) in 2015 be consist of opportunities for development of business properties, due to infrastructure development will trigger an increase in the property business in the region. BUMN (Regional-owned enterprise) of PT Pembangunan Jaya Ancol Tbk. became one of the models of local government-private partnership to successfully managing a business property in the form of a business centre area (Central Business District) in Ancol, Jakarta (Indonesia stock exchange, 2013). The owner of the company is the local Government of DKI Jakarta (72\%), PT Pembangunan Jaya (18.01\%) and public (9.99\%). PT Pembangunan Jaya Ancol Tbk. manage 500 acres of recreation zones include ha (200 ha), industrial zone and zone properties, PT Pembangunan Jaya Ancol Tbk. has provided significant contributions not only for companies but also for the local Government of DKI Jakarta as the owner of the majority of shareholders in the form of deposit PAD (the original Income areas). According to the Interior Ministry in 2013, a GRANT contribution of PAD non tax and lew Gaverment Province Jakarta is Rp. 3.252 Billion. PAD with the total amounting to Rp. 26,670.45 Billion, contributing a non tax and levy PAD of $12.19 \%$, including share profit Areas owned enterprises (BUMD) PT. Pembangunan Jaya Ancol Tbk. Government Regulation number 6/2006 on the management of State-owned goods/region stated that the assets of the State can be make by business entities, in this case including the country in which the assets of the business entity runs its business on the basis of a concession granted, or assets built by a business entity for the benefit of the Government and then operated by the business entity. Appointment of a business entity to take advantage of State assets should be done through a competitive tender process. Other forms of utilization of the goods belonging to the State or territory in the form of rent, borrow, the cooperation of utilization, wake up to the transfers (BOT) and wake up to the transfers (BTO). Governm ent Regulation number 50 year 2007 about Regional cooperation in the implementation of the Ordinance stated that the cooperation between the local governments with the business entity must be approved by the House of representatives of the region, when such cooperation resulted in the existence of the utilization of the assets local governments.

\section{RESEARCH METHODS}

This study uses qualitative methods in the form of a case study in the BPWS (development agency Area of Surabaya-Madura). The first stage of secondary data collection is done in the form of reports linked development area of Suramadu bridge, followed by the collection of primary data in the form of live interview against therelevant parties will developed the region of Suramadu bridge side of Surabaya. The second phase was conducted an analysis of the feasibility of business property in the region of Suramadu bridge sides, includes an analysis of the Net Present Value (NPV), Payback Period, and Internal Rate of Return (IRR). The third stage conducted analysis related policy cooperation of regional authorities with private parties in property development in the region of Suramadu bridge side of Surabaya. 


\begin{tabular}{|c|c|}
\hline \multicolumn{2}{|c|}{ Mixes of public \& private contributions } \\
\hline Public: & \multirow{2}{*}{$\begin{array}{l}\text { Land, Low interest loan, Grant, Cash, } \\
\text { Availability payment, Revenue guarantee } \\
\text { Equity, Debt/loan, Efficiency, new tech., } \\
\text { know-hows }\end{array}$} \\
\hline Private: & \\
\hline \multirow{4}{*}{$\begin{array}{l}\text { Due Diligence: } \\
\text { PPP Structure: } \\
\text { Bankability: } \\
\text { Risks: }\end{array}$} & Revenue vs. Expense \\
\hline & DB, BOT, BOO, DBFOMT, etc. \\
\hline & IRR culculation \\
\hline & $\begin{array}{l}\text { Construction, O\&M, E/D ratio, } \\
\text { interest rate, environmental, etc. }\end{array}$ \\
\hline
\end{tabular}

Figure 1. Model Analysis Of The Feasibility Of PPP Projects

Source: Santosa, Jatmiko, 2013

Net Present Value (NPV) of the total revenue earned during the age of the project is reduced by the total cost of the project over the age and calculated based on the present value. As the basis of calculation will be used in a particular basis, with a specific interest rate. Analysis of NPV (Net Present Value) is calculated by mendiskonto the current annual cost and revenue separately, then be obtained by the difference of these two numbers are. The method is formulated as follows:

NPV = PV ( $x$ factor income of discount $)-P V(x$ factor fee discount)

- When the NPV is negative means that development projects do not generate profit at the age of economical plan.

- When the NPV is positive means development projects can be implemented because it produces a profit at an economical plan.

- When the NPV equal to zero means that development projects can be implemented but not making a profit at an economical plan.

Payback period is the period of time required to recover the investments incurred a total present value over the generated cash flow. Internal Rate of Return (IRR) is expressed as an interest rate or discount where the present value of benefits is as great as the present value of the costs incurred at the level of interest generated. In other words the IRR is the interest rate or discount where NPV $=0$ or $=1.0 \mathrm{BCR}$. The method is formulated as follows:

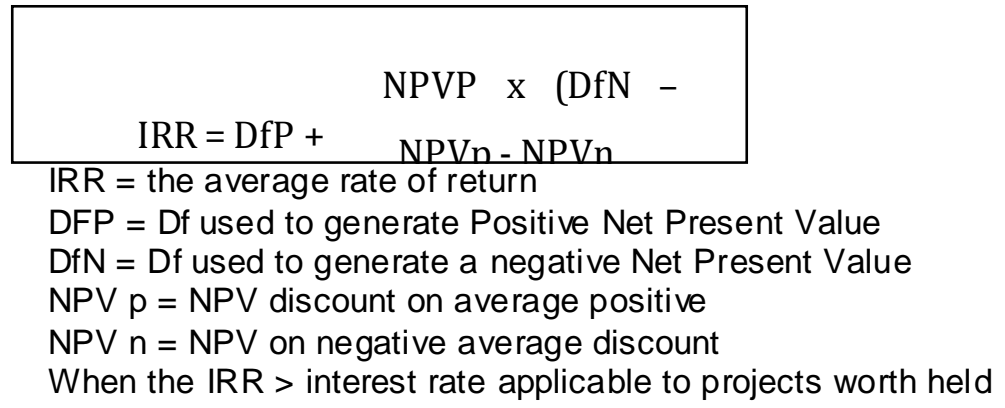




\section{RESULT AND DISCUSSION}

Central Business District generally consists of two parts, namely: (1) the very core called RBD (Retail Business District). The dominance of the activities in this section are the smart department stores, office buildings, shops, clubs, theatres, hotels and banking headquarters of economic, social, civic and political life. (2) section outside the so-called WBD (Wholesale Business District). This area is occupied by a building that is used for economic activities in large numbers such as the market, the warehouse, the storage building, (Zaw, Lin, Shwe, Theingi Hlaing \&, Maung, 2014). As the area of trade and services in the city of Surabaya, the Suramadu bridge side of Surabaya is designed such that it will be a beautiful and comfortable. Where on the basis of design planning then this region has 4 districts. Where the district has 4 different buildings as follows:

1. District 1 , a total of 6 buildings comprising:
a. Office Tower 2 building.
b. Commercial and Urban Housing as many as two buildings.
c. Urban Housing as many as 1 .
d. The apartment as much as 1 .

2. District 2, a total of 2 buildings consisting of:

a. Commercial buildings as much as 2 .

3. The District 34 buildings consisting of:

a. Urban Housing as many as 3 of the building.

b. Community center as much as 1 .

4. District 4 , a total of 11 buildings comprises:

a. Urban Housing as many as 6 buildings.

b. Commercial as much as 5 buildings.

Based on the planning which makes the planning area into 4 districts, then the magnitude of its investment will be vary between the one with other districts due to the difference in the value of land that will be built. This difference occurs because the layout of its different though in one area have resulted in the difference in the sale price of the land. Related to this, then the market price based on the estimated price of land planning can be distinguished as follows:

1. District 1, there are 6 buildings has an estimated land price of each building are as follows:

\begin{tabular}{|c|c|c|c|c|}
\hline Kode & Bangunan & $\begin{array}{l}\text { Luas Lahan } \\
\text { (M2) }\end{array}$ & $\begin{array}{l}\text { Harga/M2 } \\
\text { (Rupiah) }\end{array}$ & $\begin{array}{l}\text { Total } \\
\text { (Rupiah) }\end{array}$ \\
\hline A1 & Office Tower & 45.423 & 750.000 & $\begin{array}{l}34.067 .25 \\
0.000\end{array}$ \\
\hline A2 & Office Tower & 41.385 & 4.500 .000 & $\begin{array}{l}186.232 .5 \\
00.000\end{array}$ \\
\hline B1 & $\begin{array}{l}\text { Commercial dan } \\
\text { Urban Housing }\end{array}$ & 66.610 & 2.625 .000 & $\begin{array}{l}174.851 .2 \\
50.000\end{array}$ \\
\hline B2 & $\begin{array}{l}\text { Commercial dan } \\
\text { Urban Housing }\end{array}$ & 30.850 & 1.500 .000 & $\begin{array}{l}46.275 .00 \\
0.000\end{array}$ \\
\hline B3 & Urban Housing & 48.348 & 1.500 .000 & $\begin{array}{l}72.522 .00 \\
0.000\end{array}$ \\
\hline C3 & $\begin{array}{l}\text { Apartemen dan } \\
\text { Commercial }\end{array}$ & 42.500 & 750.000 & $\begin{array}{l}31.875 .00 \\
0.000\end{array}$ \\
\hline
\end{tabular}

Development Center For Digital Government Cooperation Patterns Of Small Medium EnterprisesPrivate To The Acceleration Of Economic Increase In Tourist Areas Joko Suyono, I Nyoman Sudapet 
2. District 2, there were 2 buildings has an estimated land price of each building are as follows:

\begin{tabular}{|l|l|c|l|l|}
\hline Kode & Bangunan & Luas Lahan (M2) & $\begin{array}{l}\text { Harga/M2 } \\
\text { (Rupiah) }\end{array}$ & Total (Rupiah) \\
\hline C1 & Commercial & 45.005 & 2.125 .000 & 89.260 .625 .000 \\
\hline C2 & Commercial & 43.250 & 500.000 & 21.625 .000 .000 \\
\hline
\end{tabular}

3. The District 3 , there are 4 building has an estimated land price of those buildings is as follows:

\begin{tabular}{|c|c|c|c|c|}
\hline Kode & Bangunan & $\begin{array}{l}\text { Luas Lahan } \\
\text { (M2) }\end{array}$ & $\begin{array}{l}\text { Harga/M2 } \\
\text { (Rupiah) }\end{array}$ & Total (Rupiah) \\
\hline D1 & Urban Housing & 39.404 & 2.125 .000 & 83.733 .500 .000 \\
\hline D2 & Urban Housing & 15.951 & 750.000 & 11.963 .250 .000 \\
\hline D3 & Urban Housing & 22.910 & 4.500 .000 & 103.095 .000 .00 \\
\hline E1 & $\begin{array}{l}\text { Commercial } \\
\text { Center }\end{array}$ & 18.165 & 2.125 .000 & 38.600 .625 .000 \\
\hline
\end{tabular}

4. District 4 , there are 11 buildings has an estimated land price of each building are as follows:

\begin{tabular}{|l|l|l|l|l|}
\hline Kode & Bangunan & $\begin{array}{l}\text { Luas Lahan } \\
\text { (M2) }\end{array}$ & $\begin{array}{l}\text { Harga/M2 } \\
\text { (Rupiah) }\end{array}$ & Total (Rupiah) \\
\hline D4 & Urban Housing & $11.147,59$ & 2.500 .000 & 27.868 .975 .000 \\
\hline D5 & Urban Housing & $9.841,75$ & 1.500 .000 & 14.762 .625 .000 \\
\hline D6 & Urban Housing & $8.225,99$ & 3.500 .000 & 28.790 .965 .000 \\
\hline D7 & Urban Housing & $8.543,62$ & 2.500 .000 & 21.359 .050 .000 \\
\hline D8 & Urban Housing & $17.350,14$ & 2.500 .000 & 43.375 .350 .000 \\
\hline D9 & Urban Housing & $22.830,63$ & 2.500 .000 & 57.076 .525 .000 \\
\hline F1 & Commercial & $12.065,58$ & 4.500 .000 & 54.295 .110 .000 \\
\hline F2 & Commercial & $11.819,35$ & 3.500 .000 & 41.367 .725 .000 \\
\hline F3 & Commercial & $21.573,07$ & 1.500 .000 & 32.359 .605 .000 \\
\hline F4 & Commercial & $17.120,96$ & 1.500 .000 & 25.681 .440 .000 \\
\hline F5 & Commercial & $10.968,71$ & 2.500 .000 & 27.396 .775 .000 \\
\hline
\end{tabular}

Based on the existing planning for the physical building construction costs in eachdistrict varies. The cost of the physical development of the building varies due to differences, differences in function and architectural beauty of the differences. So the estimated cost of each of the lowliest building planning. With regard to the foregoing, then based on the estimated cost of construction of the estimated cost of the construction of each building as follows:

1. District 1 , there are 6 buildings have estimated the cost of physical developmentare as follows:

\begin{tabular}{|l|l|l|l|l}
\hline Kode & Bangunan & $\begin{array}{l}\text { Luas } \\
\text { Bangunan } \\
\text { (M2) }\end{array}$ & $\begin{array}{l}\text { Harga/M2 } \\
\text { (Rupiah) }\end{array}$ & Total (Rupiah) \\
\hline A1 & Office Tower & 303.600 & 6.000 .000 & 1.821 .600 .000 .000 \\
\hline A2 & Office Tower & 292.100 & 6.000 .000 & 1.752 .600 .000 .000 \\
\hline B1 & $\begin{array}{l}\text { Commercial } \\
\text { dan Un Urban }\end{array}$ & 328.300 & 7.000 .000 & 2.298 .100 .000 .000 \\
\hline
\end{tabular}

Development Center For Digital Government Cooperation Patterns Of Small Medium EnterprisesPrivate To The Acceleration Of Economic Increase In Tourist Areas Joko Suyono, I Nyoman Sudapet 


\begin{tabular}{|l|l|l|l|l|}
\hline & Housing & & & \\
\hline & $\begin{array}{l}\text { Commercial } \\
\text { dan Un }\end{array}$ & & 7.000 .000 & \\
B2 & Housing & 136.400 & & 954.800 .000 .000 \\
\hline B3 & Urban Housing & 259.350 & 4.500 .000 & 1.167 .075 .000 .000 \\
\hline C3 & $\begin{array}{l}\text { Apartemen dan } \\
\text { Commercial }\end{array}$ & 158.000 & 7.500 .000 & 1.185 .000 .000 .000 \\
\hline
\end{tabular}

2. District 2, there are two buildings have estimated the cost of physical development are as follows:

\begin{tabular}{|l|l|l|l|l|}
\hline Kode & Bangunan & $\begin{array}{l}\text { Luas } \\
\text { Bangunan } \\
\text { (M2) }\end{array}$ & $\begin{array}{l}\text { Harga/M2 } \\
\text { (Rupiah) }\end{array}$ & Total (Rupiah) \\
\hline C1 & Commercial & 284.200 & 8.000 .000 & 2.273 .600 .000 \\
\hline C2 & Commercial & 182.634 & 8.000 .000 & 1.461 .072 .000 \\
\hline
\end{tabular}

3. The District 3 , there are 4 buildings have estimated the cost of physical development are as follows:

\begin{tabular}{|l|l|l|l|l}
\hline Kode & Bangunan & $\begin{array}{l}\text { Luas } \\
\text { Bangunan } \\
\text { (M2) }\end{array}$ & $\begin{array}{l}\text { Harga/M2 } \\
\text { (Rupiah) }\end{array}$ & Total (Rupiah) \\
\hline D1 & Urban Housing & $185.072,49$ & 4.500 .000 & 832.826 .705 .000 \\
\hline D2 & Urban Housing & 86.896 & 4.500 .000 & 391.032 .000 .000 \\
\hline D3 & Urban Housing & $76.816,5$ & 4.500 .000 & 345.674 .250 .000 \\
\hline E1 & Commercial Center & 31.761 & 8.000 .000 & 254.088 .000 .000 \\
\hline
\end{tabular}

4. District 4 , there are 11 buildings have estimated the cost of physical development are as follows:

\begin{tabular}{|l|l|l|l|l}
\hline Kode & Bangunan & $\begin{array}{l}\text { Luas } \\
\text { Bangunan } \\
\text { (M2) }\end{array}$ & $\begin{array}{l}\text { Harga/M2 } \\
\text { (Rupiah) }\end{array}$ & Total (Rupiah) \\
\hline D4 & Urban Housing & $19.992,29$ & 4.500 .0000 & 89.965 .305 .000 \\
\hline D5 & Urban Housing & $19.241,58$ & 4.500 .0000 & 86.587 .110 .000 \\
\hline D6 & Urban Housing & $10.368,28$ & 4.500 .0000 & 46.657 .260 .000 \\
\hline D7 & Urban Housing & 17.920 & 4.500 .0000 & 80.640 .000 .000 \\
\hline D8 & Urban Housing & 35.915 & 4.500 .0000 & 161.617 .500 .000 \\
\hline D9 & Urban Housing & 47.808 & 4.500 .0000 & 215.136 .000 .000 \\
\hline F1 & Commercial & $14.416,26$ & 8.000 .000 & 115.330 .080 .000 \\
\hline F2 & Commercial & $14.120,13$ & 8.000 .000 & 112.961 .040 .000 \\
\hline F3 & Commercial & 31.921 & 8.000 .000 & 255.368 .000 .000 \\
\hline F4 & Commercial & $116.082,51$ & 8.000 .000 & 928.660 .080 .000 \\
\hline F5 & Commercial & $38.994,4$ & 8.000 .000 & 311.955 .200 .000 \\
\hline
\end{tabular}

Development Center For Digital Government Cooperation Patterns Of Small Medium EnterprisesPrivate To The Acceleration Of Economic Increase In Tourist Areas Joko Suyono, I Nyoman Sudapet 
Based on the calculation of land and construction costs estimated the value of physical investment must be issued each building is as follows:

1. District 1, there are 6 buildings has an estimated value of investment is as follows:

\begin{tabular}{|c|c|c|c|c|}
\hline Kode & Bangunan & Biaya Lahan & Biaya Bangunan & Total (Rupiah) \\
\hline A1 & Office Tower & 34.067 .250 .000 & 1.821 .600 .000 .000 & $1.855 .667 .250 . \mathrm{C}$ \\
\hline A2 & Office Tower & 186.232 .500 .000 & 1.752 .600 .000 .000 & $1.938 .832 .500 . \mathrm{C}$ \\
\hline B1 & $\begin{array}{l}\text { Commercial } \\
\& \quad \text { Urban } \\
\text { Housing }\end{array}$ & 174.851 .250 .000 & 2.298 .100 .000 .000 & $2.472 .951 .250 . \mathrm{C}$ \\
\hline B2 & $\begin{array}{l}\text { Commercial } \\
\text { \&Urban } \\
\text { Housing }\end{array}$ & 46.275 .000 .000 & 954.800 .000 .000 & $1.001 .075 .000 . \mathrm{C}$ \\
\hline B3 & $\begin{array}{l}\text { Urban } \\
\text { Housing }\end{array}$ & 72.522 .000 .000 & 1.167 .075 .000 .000 & $1.239 .597 .000 . \mathrm{C}$ \\
\hline C3 & $\begin{array}{l}\text { Apartemen } \\
\text { dan } \\
\text { Commercial } \\
\text { TOTAL }\end{array}$ & $\begin{array}{l}31.875 .000 .000 \\
\mathbf{5 4 5 . 8 2 3 . 0 0 0 . 0 0 0}\end{array}$ & $\begin{array}{l}1.185 .000 .000 .000 \\
\mathbf{9 . 1 7 9 . 1 7 5 . 0 0 0 . 0 0 0}\end{array}$ & $\frac{1.216 .875 .000 . C}{9.724 .998 .000 . C}$ \\
\hline
\end{tabular}

2. District 2, there were 2 buildings has an estimated value of investment is as follows:

\begin{tabular}{|l|l|l|l|l|}
\hline Kode & Bangunan & Biaya Lahan & Biaya Bangunan & Total (Rupiah) \\
\hline C1 & Commercial & 89.260 .625 .000 & 2.273 .600 .000 .000 & 2.362 .860 .625 .000 \\
\hline C2 & Commercial & 21.625 .000 .000 & 1.461 .072 .000 .000 & 1.482 .697 .000 .000 \\
\hline & TOTAL & $\mathbf{1 1 0 . 8 8 5 . 6 2 5 . 0 0 0}$ & $\mathbf{3 . 7 3 4 . 6 7 2 . 0 0 0 . 0 0 0}$ & $\mathbf{3 . 8 4 5 . 5 5 7 . 6 2 5 . 0 0 0}$ \\
\hline
\end{tabular}

3. The District 3 , there are 4 building has an estimated value of investment is as follows:

\begin{tabular}{|l|l|l|l|l}
\hline Kode & Bangunan & Biaya Lahan & Biaya Bangunan & Total (Rupiah) \\
\hline D1 & Urban Housing & 83.733 .500 .000 & 832.623 .705 .000 & 916.357 .205 .000 \\
\hline D2 & Urban Housing & 11.963 .250 .000 & 391.032 .000 .000 & 402.995 .250 .000 \\
\hline D3 & Urban Housing & 103.095 .000 .000 & 345.674 .250 .000 & 448.769 .250 .000 \\
\hline & Commercial & & & \\
E1 & Center & 38.600 .625 .000 & 254.088 .000 .000 & 292.688 .625 .000 \\
\hline & TOTAL & $\mathbf{2 3 7 . 3 9 2 . 3 7 5 . 0 0 0}$ & $\mathbf{1 . 8 3 2 . 4 1 7 . 9 5 5 . 0 0 0}$ & $\mathbf{2 . 0 6 0 . 8 1 0 . 3 3 0 . 0 0 0}$ \\
\hline
\end{tabular}

4. District 4, there are 11 buildings has an estimated value of investment is as follows:

\begin{tabular}{|l|l|l|l|l}
\hline Kode & Bangunan & Biaya Lahan & Biaya Bangunan & Total (Rupiah) \\
\hline D4 & Urban Housing & 27.868 .975 .000 & 89.965 .305 .000 & 117.834 .280 .000 \\
\hline D5 & Urban Housing & 14.762 .625 .000 & 86.587 .110 .000 & 101.349 .735 .000 \\
\hline D6 & Urban Housing & 28.790 .965 .000 & 46.657 .260 .000 & 75.448 .225 .000 \\
\hline D7 & Urban Housing & 21.359 .050 .000 & 80.640 .000 .000 & 101.999 .050 .000 \\
\hline D8 & Urban Housing & 43.375 .350 .000 & 161.617 .500 .000 & 204.992 .850 .000 \\
\hline D9 & Urban Housing & 57.076 .525 .000 & 215.136 .000 .000 & $272,212,525.000$ \\
\hline F1 & Commercial & 54.295 .110 .000 & 115.330 .080 .000 & 169.625 .190 .000 \\
\hline F2 & Commercial & 41.367 .725 .000 & 112.961 .040 .000 & 154.328 .765 .000 \\
\hline F3 & Commercial & 32.359 .605 .000 & 255.368 .000 .000 & 287.727 .605 .000 \\
\hline F4 & Commercial & 25.681 .440 .000 & 928.660 .080 .000 & 954.341 .520 .000 \\
\hline F5 & Commercial & 27.396 .775 .000 & 311.955 .200 .000 & 339.351 .975 .000 \\
\hline & & $\mathbf{3 7 4 . 3 3 4 . 1 4 5 . 0 0}$ & $\mathbf{2 . 4 0 4 . 8 7 7 . 5 7 0 . 0 0}$ & \\
& TOTAL & $\mathbf{0}$ & $\mathbf{0}$ & $\mathbf{2 . 7 7 9 . 2 1 1 , 7 1 5 . 0 0 0}$ \\
\hline
\end{tabular}

Development Center For Digital Government Cooperation Patterns Of Small Medium EnterprisesPrivate To The Acceleration Of Economic Increase In Tourist Areas Joko Suyono, I Nyoman Sudapet 
Based on the calculation of the latter then total investment which can be offered to the investor is Rp. 18.410.577.670.0000,-detailed in every district as follows:

\begin{tabular}{|l|l|l|l|}
\hline \multirow{2}{*}{ Distrik } & \multicolumn{2}{|c|}{ (Rupiah) } & \multicolumn{1}{c|}{} \\
\cline { 2 - 4 } & Investasi Lahan & Investasi Bangunan & Total \\
\hline 1 & 545.823 .000 .000 & 9.179 .175 .000 .000 & 9.724 .998 .000 .000 \\
\hline 2 & 110.885 .625 .000 & 3.734 .672 .000 .000 & 3.845 .557 .625 .000 \\
\hline 3 & 237.392 .375 .000 & 1.832 .417 .955 .000 & 2.060 .810 .330 .000 \\
\hline 4 & 374.334 .145 .000 & 2.404 .877 .570 .000 & $2.779 .211,715.000$ \\
\hline \multirow{2}{*}{ TOTAL } & $\mathbf{1 . 2 6 8 . 4 3 5 . 1 4 5 . 0 0}$ & & \\
\hline
\end{tabular}

\section{CONCLUSIONS AND SUGGESTION}

The development of the Central Business District in the area of the foot side of theSurabaya Suramadu bridge as part of the supporters Small Medium Enterprises of the Center for the Digital area, refers to the development of PT Pembangunan Jaya Ancol Tbk to PAD the DKI Jakarta continues to increase, the company's contribution towards 2012 year PAD Jakarta reached Rp. 129.2 Billion or larger than in2011 that reached Rp. 120.8 billion, us $\$ 77.37$ billion in local tax is payable and the remaining Rp 51.84 Billion from dividends. The contribution of PT Pembangunan Jaya Ancol Jakarta to PAD within 5 (five) last year continues to increase, the year 2007 reached Rp. contributions to 90.25 billion and increased to USD 100.9 Billion in year 2008. For the year 2009 reached $\mathrm{Rp}$ 100.7 billion, in the year 2010 amounted to Rp. 113.2 billion and in the year 2011 to $\mathrm{Rp}$. 120.8 billion. So with the total investment being offered to investors is Rp. 18.410.577.670.0000,-will surely be very attractive.

\section{REFERENCES}

Badan Koordinasi Penanaman Modal (2014) Realisasi Penanaman Modal PMDN-PMA Q42014, Jakarta, bkpm.go.id

Bank Dunia \& IFC (2012) Doing Business di Indonesia: membandingkan kebijakan usaha di 20 kota dan 183 perekonomian, The World Bank, Washington DC USA

Bank Dunia \& IFC (2013) Doing Business 2014: Understanding Regulations for Small and Medium-Size Enterprises, The World Bank, Washington DC USA

Bank Indonesia (2014) Perkembangan Properti Komersial-Triwulan III 2014, Jakarta, bi.go.id

Boston Consulting Group (2013) Asia's Next Big Opportunity: Indonesia's Rising Middle-Class and Affluent Consumers, bcg.com

Bursa Efek Indonesia (2013) Performance Summary PT Pembangunan Jaya Ancol Tbk, idx.co.id

Bursa Efek Indonesia (2014) IDX Statistics 2014, BEI Research Divisions, idx.co.id

Direktorat Jenderal Pesisir dan Pulau-Pulau Kecil (2006) Pedoman Kota Pesisir, Kementerian Kelautan dan Perikanan, Jakarta

Fulyaningtyas, Septerina (2009) Arahan Pengembangan Pantai Timur Surabaya Sebagai Kawasan Ekowisata, ITS: Jurusan PWK, Surabaya

Kementerian Dalam Negeri (2010) Neraca APBD 2010, Kementerian Dalam Negeri RI, Jakarta

Kementerian Dalam Negeri (2013) Postur APBD Tahun Anggaran 2013, Kementerian Dalam Negeri Rl, Jakarta

Peraturan Pemerintah no. 50 tahun 2007 tentang Tata Cara Pelaksanaan Kerjasama Daerah

Rahmat, Adipati (2010) Jakarta Waterfront City, adipatirahmat.wordpress.com

Santosa, Jatmiko (2013) Public Private Partnership in Indonesia \& ASEAN-East Java Case

Development Center For Digital Government Cooperation Patterns Of Small Medium EnterprisesPrivate To The Acceleration Of Economic Increase In Tourist Areas Joko Suyono, I Nyoman Sudapet 
Study, PT Sarana Multi Infrastruktur (Persero), Jakarta

Santoso, Urip (2013) Hukum Agraria; Kajian Komprehensif, Jakarta

The Economist (2015) Investing Into Asia's Reform Landscape: Asia Business Outlook Survey 2015, The Economist Corporate Network

Tiffin R (1999) Practical Techniques for Effective Project Investment Appraisal, Hawksmere PLC UNCTAD United Nations Conference on Trade and Development (2013) World Investment Prospects Survey 2013-2015, United Nations, New York and Geneva

Undang Undang no. 22 Tahun 1999 \& UU no.34 tahun 2004 tentang Otonomi Daerah

Zaw, Lin, Shwe, Theingi \& Hlaing, Maung (2014) Studies of the Status of Central Business District Area (CBD) in Yangon, Myanmar, International Journal of Emerging Technology and Advanced Engineering, Volume 4, Issue 5, May 2014 